\title{
Program Sekolah dalam Upaya Pencegahan NAPZA
}

\author{
Fidrayani, Desiana Utami \\ UIN Syarif Hidayatullah Jakarta, Indonesia \\ E-mail: fidrayani7276@uinjkt.ac.id
}

\begin{abstract}
Narcotics in unattended use can have a negative impact. The impact is potential to destroy the youth generation. It is necessary to hold the drug prevention programs, especially in schools as one of ways to prevent the widespread negative impact. The prevention can be through the role of parents, teachers and stakeholders as part of the community. The teachers' role is divided into four sub-role, namely as educators, as advisors, as mentors, and particularly as problem solvers. The role of teachers certainly will not have power if it is not supported by the role of schools. Effots that are conducted by school stakeholder are as follow: a) compose the school rules; b) conduct inspections intensively and spontaneously; c) cooperate with related institutions for counseling and socialization; d) utilize extracurricular activities as means of prevention; e) integrate drug awareness into learning curriculum; (f) maximize the tasks as the effort of drug abuse prevention. Expectedly, these drug prevention efforts can be implemented by all schools as one of ways to prevent the destruction of the nation through NAPZA.
\end{abstract}

Keywords: school program; drug abuse; NAPZA

Abstrak. Narkoba dalam penggunaan yang tidak diawasi dapat menimbulkan dampak negatif. Dampak tersebut tidak menutup kemungkinan dapat merusak generasi muda. Salah satu cara agar bahaya tersebut tidak meluas dampaknya, maka perlu program pencegahan terutama di sekolah. Pencegahan tersebut dapat melalui peran orang tua, guru dan pemangku kebijakan sebagai bagian dari masyarakat. Peran guru dibagi dalam empat yakni sebagai pendidik, penasehati, pembimbing dan lebih utama lagi sebagai problem solver. Peran guru ini tentu tidak akan memiliki kekuatan jika tidak didukung oleh peran sekolah. Upaya yang dilakukan oleh pihak sekolah adalah a) membuat tata tertib sekolah, b) melakukan razia intensif dan spontan, c) bekerjasama dengan instansi terkait guna penyuluhan dan sosialisasi, d) menggunakan ekstrakurikuler sebagai sarana pencegahan, e) memasukkan materi tentang narkotika ke dalam kurikulum pengajaran, f) memaksimalkan tugas dalam upaya pencegahan penyalahgunaan NAPZA. Diharapkan agar upaya pencegahan tersebut dapat diikuti oleh semua sekolah sebagai salah satu usaha untuk mencegah rusaknya anak bangsa melalui NAPZA.

Kata Kunci: program sekolah; penyalahgunaan; NAPZA

Permalink/DOI: 10.15408/harkat.v14i1.10406 


\section{Pendahuluan}

Narkoba atau yang sekarang dikenal dengan sebutan NAPZA adalah kepanjangan dari narkotika, psikotropika, dan bahan adiktif lainnya yang merupakan sekelompok obat, yang berpengaruh pada kerja tubuh, terutama otak. Di satu sisi NAPZA merupakan obat atau bahan yang bermanfaat di bidang pengobatan, pelayanan kesehatan, dan pengembangan ilmu pengetahuan. Namun, di sisi lain dapat menimbulkan ketergantungan apabila dipergunakan tanpa adanya pengendalian.

Peredaran dan penyalahgunaan NAPZA merupakan salah satu permasalahan nasional yang dipandang serius oleh pemerintah, karena dapat menyebabkan rusaknya moral bangsa. Karena itu pemerintah sangat memberikan perhatian terhadap penanganan atas penyalahgunaan NAPZA. Di negara kita, masalah merebaknya penyalahgunaan NAPZA semakin lama semakin meningkat. Dampak dari penyalahgunaan NAPZA tidak hanya mengancam kelangsungan hidup dan masa depan penyalahgunanya saja, namun juga masa depan bangsa dan negara, tanpa membedakan strata sosial, ekonomi, usia maupun tingkat pendidikan (Rinny Agustin, 2014)

Pengguna NAPZA sudah menjalar pada usia muda. Tidak sedikit orang yang mulai menggunakan NAPZA masih duduk di bangku SD, SMP, dan SMA. Dapat dibayangkan bagaimana masa depan bangsa ini bila generasi mudanya sudah diracuni oleh NAPZA.

\section{Penyalahgunaan NAPZA dapat} mengganggu suasana di sekolah. Sekolah menjadi tidak nyaman, meningkatnya kenakalan pada siswa, siswa menjadi sering membolos, hingga ada yang harus putus sekolah. Banyak di antara mereka yang menjadi pengedar lalu mencuri barang milik teman atau karyawan sekolah.
Berdasarkan data dari Badan Narkotika Nasional (BNN), kasus penyalahgunaan NAPZA di Indonesia terus meningkat pada lima tahun terakhir dari tahun 2009 sampai dengan tahun 2013. Kasus penyalahgunaan NAPZA di kalangan pelajar mencapai angka 797 kasus. Di tingkat Sekolah Dasar (SD) mencapai 48 kasus, Sekolah Menengah Pertama (SMP) 124 kasus, Sekolah Menengah Atas (SMA) 470 kasus (Tri Wulandari, 2016).

Kasus penyalahgunaan narkoba, psikotropika, dan zat adiktif lainnya (NAPZA) di Indonesia dari tahun ke tahun juga terus mengalami kenaikan dimana pada tahun 2008 ada sebanyak 3.3 juta (3.362.527) dengan pravalensi $1,99 \%$ menjadi pada tahun 2011 menjadi 4 juta (4.071.016) dengan pravalensi 2,32\% dan diprediksikan angka tersebut akan terus mengalami kenaikan pada tahun 2015 menjadi 5,1 juta $(5.126 .913)$ dengan pravalensi 2,8\%. Diketahui $5,3 \%$ di antaranya adalah kalangan pelajar dan mahasiswa (Qomariyatus Sholihah, 2015).

Melihat penyalahgunaan NAPZA yang melanda para pelajar, maka dapat dipastikan bahwa keadaan generasi penerus bangsa saat ini cukup memprihatinkan, karena penyalahgunaan NAPZA tidak hanya mengganggu keamanan dan ketertiban, melainkan sudah mengarah pada tindak kriminal. Sekolah sebagai lembaga pendidikan mempunyai peran yang sangat besar dalam melakukan upaya pencegahan terhadap penyalahgunaan NAPZA melalui berbagai program yang dilaksanakan di sekolah.

Dalam hal ini, pelajar di setiap sekolah tidak terlepas dari adanya peran guru untuk membimbing siswa dalam memecahkan permasalahan yang dihadapi dengan mengarahkan siswa pada perilaku yang lebih positif, mengembangkan kemampuan siswa, serta memberikan motivasi belajar kepada siswa.

Upaya pencegahan penyalahgunaan NAPZA termasuk peran dari lembaga 
pendidikan yaitu sekolah secara terus menerus dan berkesinambungan berupaya mengubah sikap, perilaku, serta cara berpikir siswa agar terhindar dari bentuk kejahatan NAPZA. Upaya ini bertujuan untuk menciptakan kesadaran siswa agar lebih waspada dan mengantisipasi terhadap segala bentuk bahaya yang dapat ditimbulkan dari penyalahgunaan NAPZA.

Berdasarkan hasil observasi dan wawancara di SMK 41 Jakarta, perangkat sekolah menyatakan bahwa ada program yang disusun oleh sekolah dalam melakukan upaya pencegahan penyalahgunaan NAPZA pada siswa. Sekolah melakukan upaya pencegahan untuk menghindari terjadinya perilaku mengkosumsi NAPZA pada siswa yang sangat mudah di pengaruhi oleh lingkungan dan teman sebaya.

Berdasarkan latar belakang masalah tersebut maka peneliti tertarik untuk melakukan penelitian dan mengumpulkan data-data yang relevan serta mengolahnya dalam sebuah penelitian dengan judul "Program Sekolah dalam Upaya Pencegahan Penyalahgunaan NAPZA di SMK 41 Jakarta”. Berdasarkan latar belakang yang telah dipaparkan diatas, maka rumusan masalah dalam penelitian ini adalah “apa saja program sekolah yang dilaksanakan dalam upaya pencegahan penyalahgunaan NAPZA?"

\section{Narkoba, Psikotropika, dan Zat Adiktif Lainnya (NAPZA)}

NAPZA adalah zat yang jika dimasukan dalam tubuh manusia, baik secara oral/diminum, dihirup, maupun disuntikan, dapat mengubah pikiran, suasana hati atau perasaan, dan perilaku seseorang. NAPZA dapat menimbulkan ketergantungan (adiksi) fisik dan psikologis (Maudy Pritha Amanda, dkk., 2017).

Saat ini narkoba dikenal pula dengan istilah NAPZA. NAPZA adalah singkatan dari narkotika, psikotropika, dan zat adiktif. Narkotika disebut juga sebagai obat-obatan anastesi, penggunaan narkotika dapat mengakibatkan kehilangan kesadaran karena pengaruh sistem susunan saraf pusat. Narkotika merupakan obat yang berasal dari tanaman yang dapat menyebabkan hilang kesadaran dan dapat menimbulkan ketergantungan. Berdasarkan Undang-Undang No.5 Tahun 1997, psikotropika adalah zat atau obat, baik alamiah maupun sintetis bukan narkotika, yang berkhasiat psikoaktif melalui pengaruh selektif pada susunan saraf pusat yang menyebabkan perubahan khas pada aktivitas mental dan perilaku. Zat adiktif adalah bahan yang dapat menimbulkan kerugian bagi seseorang yang menggunakannya akibat timbulnya ketergantungan psikis seperti golongan alkohol, nikotin dan sebagainya. Jenis-jenis NAPZA antara lain heroin, morfin, ganja, ekstasi, sabusabu, obat penenang, dan alkohol (Qomariyatus Sholihah, 2015).

NAPZA merupakan jenis obat yang diperlukan dalam dunia pengobatan. Tetapi jika digunakan tanpa pengawasan dan pembatasan dapat menimbulkan ketergantungan dan membahayakan jiwa pemakainya.

Jenis-jenis NAPZA

Menurut A. Kadarmanta (2010: 48-53) terdapat beberapa jenis NAPZA, yaitu:

a) Candu, adalah zat yang dihasilkan dari tanaman berbunga papaver somniferum $L$, yang berisi berbagai macam Zat kimia aktif.

b) Heroin, adalah Zat yang dihasilkan oleh pohon candu, yang memiliki daya adiktif sebesar 30 kali candu kasar.

c) Depresan, adalah vat yang menekan susunan syaraf pusat dengan akibat rasa tenang dan mengantuk.

d) Stimulan, adalah Zat yang bila digunakan menimbulkan stimulus atau rangsangan 
yang bersifat bersemangat, gembira, berkhayal tinggi, percaya diri besar, dan mempunyai energy tak terbatas.

e) Pil ekstasi, adalah Zat yang bila digunakan menyebabkan terjadi perubahan persepsi sehingga hati menjadi gembira berlebihan, keinginan bergerak dalam musik, gerakan berlebih, dan lainnya.

f) Inhalan, adalah Zat yang mudah menguap seperti campuran cat, lem, da sejenisnya. Senyawa aktif dalam benda-benda tersebut dapat mempengaruhi pertumbuhan dan perkembangan otot-otot, syaraf, dan organ lain, dan dapat mengakibatkan masalah sumsum tulang.

\section{Faktor Penyebab Penyalahgunaan NAPZA}

Menurut Hari Sasangka (2003: 89) beberapa faktor penyebab penyalahgunaan NAPZA diantaranya:

a) Untuk membuktikan keberanian dalam melakukan tindakan yang berbahaya

b) Untuk menantang suatu otoritas terhadap orang tua, guru, hukum, atau instansi yang berwenang

c) Mempermudah penyaluran dan perbuatan seksual

d) Melepaskan diri dari rasa kesepian dan memperoleh pengalaman emosional

e) Agar dapat menemukan arti hidup

f) Mengisi kekosongan dan perasaan bosan

g) Untuk menghilangkan rasa frustasi dan kegelisahan yang disebabkan problema yang tidak bisa diatasi

h) Untuk memupuk solidaritas dengan kawan-kawan

i) Karena didorong rasa ingin tahu
Para pelajar sekolah menengah atas sedang berada pada fase remaja yang sedang menemukan jati dirinya. Terkadang remaja tersebut dihampiri rasa galau, dan saat itu remaja dapat dengan mudah dipengaruhi, termasuk dipengaruhi kearah yang negatif. Pengaruh tersebut salah satunya dapat berasal dari teman sebaya. Biasanya mereka akan melakukan apapun agar remaja tersebut dapat dikatakan memiliki solidaritas dengan teman. Bila remaja tersebut tidak memiliki dorongan yang kuat untuk menolak ajakan negatif dari temannya, maka remaja tersebut dapat melakukan hal negatif termasuk melakukan penyalahgunaan NAPZA.

\section{Tanda-tanda Pengguna NAPZA}

Bagi pengguna NAPZA, terdapat perubahan perilaku yang dapat dikenali oleh orang-orang disekitarnya. Menurut Hari Sasangka (2003: 94), berikut beberapa tandatanda anak yang mempunyai masalah dengan NAPZA:

\begin{tabular}{|c|c|}
\hline $\begin{array}{ll}\text { Sebelum memakai } \\
\text { NAPZA }\end{array}$ & $\begin{array}{l}\text { Sesudah memakai } \\
\text { NAPZA }\end{array}$ \\
\hline Riang & $\begin{array}{l}\text { Menjadi pendiam, } \\
\text { suka memendam rasa }\end{array}$ \\
\hline Sehat & Menjadi sakit-sakitan \\
\hline Bertenaga & Menjadi loyo \\
\hline Percaya diri & Menjadi peragu \\
\hline Sabar & $\begin{array}{l}\text { Menjadi mudah putus } \\
\text { asa }\end{array}$ \\
\hline Bersemangat & $\begin{array}{l}\text { Menjadi } \\
\text { semangat }\end{array}$ \\
\hline Rajin sekolah & $\begin{array}{l}\text { Menjadi suka } \\
\text { membolos }\end{array}$ \\
\hline $\begin{array}{l}\text { Ada perhatian kepada } \\
\text { orang lain }\end{array}$ & $\begin{array}{l}\text { Menjadi acuh tak } \\
\text { acuh, egois }\end{array}$ \\
\hline Hemat & $\begin{array}{l}\text { Menjadi boros, sering } \\
\text { minta uang, dan } \\
\text { kadang-kadang } \\
\text { mencuri }\end{array}$ \\
\hline
\end{tabular}


Selain itu, Badan Narkotika Nasional (2011: 43-45) menyatakan terdapat beberapa ciri perkembangan remaja yang rentan terhadap permasalahan penyalahgunaan NAPZA, antara lain:

\section{a) Perasaan galau}

Anak remaja sering mengalami ketegangan, perasaan tertekan, keresahan, kebingungan, dan frusstasi, sehingga berisiko tinggi menyalahgunakan narkoba.

b) Perasaan ingin tahu

Pada masa remaja ada dorongan untuk mengeksplorasi dunia sekitar, mencoba pengalaman baru, termasuk mencoba-coba narkoba.

\section{c) Kegoncangan emosional}

Dengan adanya perubaha-perubahan psikologis secara mendalam dan mendadak pada masa remaja, maka seringkali remaja dalam hal penyalahgunaan narkoba digolongkan menjadi kelompok berisiko tinggi.

\section{d) Cenderung melawan otoritas}

Pada masa remaja, ada dorongan untuk melawan otoritas dan mementang nilai-nilai yang diakui masyarakat orang dewasa, untuk mencari identitas dirinya

\section{e) Tekanan kelompok sebaya}

Remaja memiliki kebutuhan untuk diterima dan diakui oleh kelompok sebayanya. Jika kelompok sebaya tidak memiliki nilai-nilai positif, remaja akan terjerumus dalam berbagai perbuatan berbahaya.

\section{Dampak Penyalahgunaan NAPZA}

Dampak penyalahgunaan zat adiktif terhadap siswa yaitu dapat berdampak pada dirinya sendiri, keluarga, sekolah dan juga masyarakat atau lingkungannya. Bagi siswa itu sendiri yaitu akan berdampak pada terganggunya fungsi otak dan perkembangan normal, keracunan, bahkan menyebabkan kematian dan perdarahan otak, gangguan perilaku atau mental sosial seperti sikap acuh tak acuh maupun sulit mengendalikan diri, gangguan kesehatan juga kendornya nilai kehidupan agama, sosial maupun budaya sepert seks bebas, sopan santun hilang dan lebih mementingkan diri sendiri. Bagi sekolah akan merusak disiplin dan motivasi yang sangat penting bagi proses belajar mengajar (Ratna Umi Nurlila dan Jumarddin La Fua, 2017).

Pada anak-anak, remaja bahkan dewasa yang terkena tindak penyalahgunaan NAPZA dapat menyebabkan dampak negatif seperti perubahan sifat atau kepribadiannya, misalnya dulu mempunyai sifat dan kepribadian yang ramah tamah akan berubah menjadi pendiam, suka mengurung diri dikamar, tidak suka bergaul dengan lingkungan sekitar, serta menutup diri dan lain-lain. Dampak yang paling parah adalah menyebabkan overdosis hingga berujung kematian (Titi Andriani, 2011).

Dampak dari penyalahgunaan NAPZA bagi pelajar sangat mengerikan. Untuk fisik mereka, NAPZA dapat menyebabkan ketergantungan, kecanduan, terganggunya fungsi otak, hingga dapat menyebabkan kematian. Selain itu, NAPZA dapat menyebabkan perubahan kepribadian orang yang memakainya, dari kepribadian positif menjadi negatif. Ketika mereka sudah ketergantungan dan menjadi pecandu, mereka akan berusaha melakukan apapun. Mereka tidak segan-segan untuk berbohong pada orang tua bahkan mereka mencuri agar mereka mendapatkan narkoba tersebut.

\section{Upaya Pencegahan Penyalahgunaan NAPZA}

Pelajar pada pendidikan menengah merupakan obyek sekaligus subyek didik yang secara emosional masih labil, sehingga rentan 
untuk melakukan kenakalan salah satunya menjadi penyalahguna NAPZA. Mereka perlu memiliki ketahanan diri agar dapat mengendalikan dirinya dari rasa ingin tahu dan ajakan teman untuk mencoba NAPZA. Selain itu diperlukan juga dukungan positif dari lingkungan sekolah, masyarakat, maupun orang tua agar mereka terhindar dari penyalahgunaan NAPZA.

Salah satu program pencegahan penyalahgunaan NAPZA adalah dengan menyediakan pelatihan life skill yang diberikan kepada anak maupun orang tua. Pelatihan tersebut dapat berupa penyuluhan narkoba. Penyuluhan yang dimaksud adalah penyuluhan yang ditujukan kepada orang tua untuk meningkatkan pengetahuan tentang NAPZA sebagai upaya menjaga anak untuk tidak terjerumus dalam penyalahgunaan NAPZA (Fahrul Rozi, 2015).

Menurut Rahmiyati (2015), dalam konteks pencegahan terhadap berkembangnya penyalahgunaan NAPZA pada remaja dibutuhkan pilar utama dalam membentenginya, yaitu:

\section{a) Setiap Orang}

Bagi orang beragama Islam, NAPZA adalah barang haram yang harus dijuahi, sehingga bagi setiap orang pemeluk Islam wajib berpegang teguh untuk tidak mengkonsumsi NAPZA. Setiap orang sejak dini harus menanamkam penolakan terhadap NAPZA dengan membentuk opini se negatif mungkin terhadap NAPZA. "Hai orang-orang yang beriman sesungguhnya minuman keras, berjudi, berkurban untuk berhala dan mengundi nasib dengan panah, adalah perbuatan keji termasuk perbuatan syaitan. Maka jauhilah perbuatan perbuatan itu agar kamu mendapat keberuntungan" (Qs. Al Maaidah: 90). b) Orang tua

Orang tua yang pertama adalah orang tua ayah dan ibu kandung. Selain itu orang tua adalah orang-orang dewasa yang ada disekitar anak-anak. "Apakah mereka mengira bahwa harta dan anak-nak yang Kami berikan kepada mereka itu (berarti bahwa) Kami segera memeberikan kebaikan kebaikan kepada meraka? Tidak, sebenarnya mereka tidak sadar (QS. Al mu'minuun:55-56). Para orangtua harus menampakan sikap antipati terhadap NAPZA, dan melakukan bimbingan, pengawasan terhadap anak-anak di lingkungannya.

\section{c) Pendidik}

Garda terdepan pendidik di sekolah adalah guru. Semua guru sebagai pendidik bertanggung jawab penuh bagi berkembangnya siswa ke arah yang lebih baik, mampu hidup mandiri dan berakhlak mulia. NAPZA merupakan racun yang paling berbahaya dan mematikan bagi perkembangan siswa baik aspek fisik, mental, spiritual.

d) Tokoh Agama dan penyuluh Agama

Peran Alim ulama dan penyuluh agama dalam menjauhkan NAPZA di masyarakat sangat efektif. Para Alim ulama dan Penyuluh agama mempunyai daya sugestibel dalam membawa umat ke arah yang lebih baik. Dengan maraknya penyalahgunaan NAPZA di masyarakat peran ulama dan penyuluh agama sangat urgen, bahkan dengan adanya ulama dan penyuluh agama dapat menjadi penangkal bagi peredaran NAPZA di suatu daerah.

Dalam konteks pencegahan terhadap berkembangnya penyalahgunaan NAPZA pada remaja dibutuhkan beberapa upaya yaitu dari masyarakat, orang tua, tokoh agama, dan tidak lupa melalui pendidikan. Pendidikan penanggulangan penyalahgunaan obat merupakan bagian dari program pendidikan nasional berdasarkan Pancasila dalam mempertinggi budi pekerti, memperkuat 
kepribadian, dan menumbuhkan manusiamanusia pembangunan yang dapat membangun dirinya sendiri serta bersama-sama bertanggung jawab atas pembangunan bangsa. Tugas tersebut adalah dalam rangka mencerdaskan bangsa, khususnya dalam mempersiapkan generasi mendatang. Hasil pendidikan diharapkan akan dapat mewujudkan pola budaya bangsa, baik moral maupun mental, dalam membentuk suatu kultur yang anti kepada penyalahgunaan NAPZA, serta menempatkan kedudukan obat pada tempat sewajarnya yaitu untuk mengobati penyakit dan bukan untuk disalahgunakan (Sumarmo Masum, 1987: 125).

Peran sekolah sangat menentukan, sekolah sebagai sebuah institusi dan sarana sosialisasi merupakan sebuah media yang sangat tepat untuk senantiasa selalu mengingatkan dan mengimbau siswa siswinya untuk senantiasa selalu menjauhi penyalahgunaan NAPZA, hal ini dapat dilakukan pihak sekolah melalui berbagai metode, baik secara ceramah, media luar ruang maupun aktifitas-aktifitas lainnya (Abrar Adhani \& Ribut Priyadi, 2017).

Peran guru dalam upaya pencegahan penyalahgunaan NAPZA terbagi kedalam 4 garis besar. Pertama, guru sebagai pendidik. Guru memiliki wibawa, tanggung jawab, moral dan sosial. Kedua, guru sebagai pembimbing. Guru dapat membimbing berdasarkan pengetahuan yang dimiliki tentang bahaya NAPZA. Ketiga, guru sebagai penasehat, dapat berbicara secara terbuka, problem solving, bimbingan konseling. Terakhir sebagai model atau teladan, menjadi panutan bagi siswa siswinya. (http://bali.bnn.go.id/uncategorized/pembinaanfasilitator-peran-guru-dalam-mencegah-narkobadi-sekolah/).

Program pencegahan penyalahgunaan NAPZA disekolah dapat dibuat menjadi satu kesatuan dengan program manajemen peningkatan mutu berbasis sekolah yang terimplementasikan dalam pengembangan, pelaksanaan dan evaluasi kurikulum. (Djuharis Rasul, 2013). Pendidikan pencegahan penyalahgunaan NAPZA disekolah perlu diterapkan dalam bentuk sosialisasi kepada komite sekolah, masyarakat, lembaga-lembaga, dan Unit Kesehatan Sekolah (UKS), kemudian dapat menyampaikan pengetahuan tentang bahaya penyalahgunaan NAPZA kepada siswa. Selain itu, pembelajaran tentang bahaya penyalahgunaan NAPZA dapat dilaksanakan dengan menggabungkan materi terkait bahaya NAPZA kedalam mata pelajaran atau dalam kegiatan ekstrakulikuler.

\section{Metode}

\section{Jenis Penelitian}

Penelitian yang digunakan dalam penelitian ini adalah deskriptif kualitatif. Penelitian kualitatif adalah penelitian yang naturalistik karena penelitiannya dilakukan pada kondisi yang alamiah (Sugiyono, 2011). Selain itu menurut Andi Misna (2015), penelitian deskriptif kualitatif adalah jenis penelitian yang berusaha menggambarkan obyek atau subyek yang diteliti sesuai dengan apa adanya dengan tujuan menggambarkan secara sistematis fakta dan karakteristik obyek yang diteliti secara tepat. Melalui penelitian deskriptif kualitatif, peneliti berusaha menjelaskan atau mendeskripikan suatu fenomena yang sesuai dengan yang ada di lapangan berdasarkan permasalahan yang terjadi, mendeskripsikan peristiwa dan kejadian yang menjadi pusat perhatian tanpa memberikan perlakuan khusus terhadap peristiwa tersebut.

Jadi, penelitian deskriptif kualitatif dalam penelitian ini adalah untuk mendeskripsikan dan mengetahui bagaimana implementasi program sekolah dalam upaya pencegahan penyalahgunaan NAPZA pada pelajar SMK 41 Jakarta. 


\section{Sumber Data}

Dalam suatu penelitian, sumber data sangat diperlukan untuk melengkapi pendeskripsian penelitian. Sumber data pada penelitian ini diperoleh melalui narasumber dengan cara melakukan wawancara dengan guru yang termasuk dalam bidang kesiswaan sekaligus koordinator guru bimbingan konseling di SMK Negeri 41 Jakarta, terkait dengan program sekolah dalam rangka pencegahan penyalahgunaan narkoba.

\section{Teknik Pengumpulan Data}

Penelitian kepustakaan atau library research, yaitu memanfaatkan perpustakaan sebagai sarana dalam mengumpulkan data, dengan mempelajari buku-buku sebagai bahan referensi. Penelitian lapangan dengan melakukan observasi, yaitu pengumpulan data melalui pengamatan langsung, dan wawancara, yaitu mengumpulkan data dengan cara mengajukan pertanyaan langsung kepada seorang informan.

\section{Hasil dan Pembahasan}

Berdasarkan hasil observasi dilapangan menunjukkan bahwa SMK 41 sudah memaksimalkan program sekolah dalam upaya pencegahan penyalahgunaan NAPZA sesuai dengan peraturan sekolah. Terlihat saat pagi hari terdapat pemeriksaan terhadap perlengkapan yang siswa bawa sebelum memasuki lingkungan sekolah. Selain itu juga dilaksanakan razia secara spontan guna memastikan bahwa tidak ada siswa yang menggunakan obat-obatan, rokok, maupun mengkonsumsi minuman beralkohol di lingkungan sekolah. Guru beserta staff yang ada di sekolah juga tidak ada yang merokok di lingkungan sekolah. Hal itu karena guru merupakan role mode yang akan ditiru oleh siswa, sehingga para guru tidak melakukan kegiatan yang demikian disekolah.

\section{Hasil wawancara}

Berdasarkan hasil wawancara, sekolah memiliki beberapa program upaya pencegahan penyalahgunaan NAPZA di kalangan siswa. Program tersebut ialah :

\begin{tabular}{|c|c|}
\hline No. & Implementasi Program \\
\hline \multirow[t]{3}{*}{1.} & Membuat tata tertib sekolah, seperti: \\
\hline & $\begin{array}{l}\text { Dilarang membawa rokok } \\
\text { kedalam lingkungan sekolah }\end{array}$ \\
\hline & $\begin{array}{l}\text { Dilarang membawa minuman } \\
\text { beralkohol kedalam lingkungan sekolah }\end{array}$ \\
\hline 2. & Melakukan razia intensif secara berkala \\
\hline 3. & Melakukan razia secara spontan \\
\hline 4. & $\begin{array}{l}\text { Memaksimalkan tugas guru dalam upaya } \\
\text { pencegahan penyalahgunaan NAPZA }\end{array}$ \\
\hline 5 . & $\begin{array}{l}\text { Melakukan kerjasama penyuluhan dan } \\
\text { sosialisasi bahaya penyalahgunaan } \\
\text { NAPZA dengan beberapa pihak terkait }\end{array}$ \\
\hline 6. & $\begin{array}{l}\text { Menggunakan ekstrakulikuler sebagai } \\
\text { upaya pencegahan }\end{array}$ \\
\hline 7. & $\begin{array}{l}\text { Memasukkan materi NAPZA dalam } \\
\text { kurikulum pengajaran }\end{array}$ \\
\hline 8. & $\begin{array}{l}\text { Memasukkan materi NAPZA dalam } \\
\text { kegiatan upacara }\end{array}$ \\
\hline
\end{tabular}

Dalam memaksimalkan peran guru dalam upaya pencegahan penyalahgunaan NAPZA, sekolah melakukan beberapa kegiatan bersama siswa seperti coffee morning yang dilakukan dalam rangka sharing beberapa permasalahan yang ada di kalangan remaja dan juga cara mencegah agar siswa tidak terlibat dalam permasalahan tersebut. Pada kegiatan ini juga membahas bahaya NAPZA, agar siswa memiliki bekal pengetahuan terkait bahaya penyalahgunaan NAPZA dan siswa tidak terjerumus kedalam hal negatif seperti itu. Kegiatan tersebut dilaksanakan oleh siswa dan masing-masing wali kelas pada hari senin usai kegiatan upacara bendera. Selain itu, pihak sekolah juga melakukan kunjungan ke rumah keluarga siswa yang memiliki permasalahan kehidupan yang dapat memungkinkan siswa bisa menggunakan NAPZA. 
Sekolah juga mengadakan razia baik secara intensif maupun spontan. Hal ini dapat membuat siswa untuk taat terhadap aturan yang berlaku di sekolah. Selain itu juga untuk menjaring siswa yang kedapatan melanggar aturan sekolah sehingga siswa tersebut bisa di berikan peringatan dan diberikan arahan agar kejadian yang sama tidak terulang lagi.

Dalam hal kegiatan kerjasama penyuluhan dan sosialisasi bahaya NAPZA, pihak sekolah melakukan kerjasama dengan beberapa pihak seperti Kepolisian, Marinir, BNN, serta Dinas Kesehatan. Kegiatan penyuluhan tersebut dilaksanakan bersamaan dari siswa kelas 10 hingga kelas 12 di lapangan sekolah, dan terkadang dilakukan secara bergiliran di aula sekolah. Kegiatan sosialisasi ini bertujuan agar siswa mendapatkan pengetahuan yang lebih terkait bahaya NAPZA, baik bahaya untuk kesehatan dan juga masa depan. Siswa juga dapat mengetahui hukum yang berlaku untuk orang yang melakukan penyalahgunaan NAPZA.

Sekolah juga menjadikan kegiatan ekstrakulikuler sebagai upaya pencegahan penyalahgunaan NAPZA seperti pada ekstrakulikuler keagamaan. Dalam ekstrakulikuler keagamaan, siswa akan mendapatkan bekal pengetahuan agama yang akan menguatkan diri siswa agar tidak terjerumus kedalam kegiatan yang dilarang oleh agama. Selain pada ekstrakulikuler keagamaan, dalam ekstrakulikuler olahraga dan ekstrakulikuler pramuka juga dapat mencegah siswa dari upaya penyalahgunaan NAPZA. Dengan mengikuti ekstrakulikuler tersebut, secara fisik siswa akan menjadi sehat dan kuat dan tidak akan tergiur dengan efek-efek jika menggunakan NAPZA. Selain itu juga ekstrakulikuler mading membantu sekolah untuk memberikan informasi secara tertulis kepada siswa terkait bahaya NAPZA, yang selanjutnya informasi tersebut ditempel pada mading sekolah.
Dalam kurikulum pengajaran, sekolah memasukkan upaya pencegahan penyalahgunaan NAPZA dalam pelajaran Pendidikan Kewarganegaraan, Agama, dan Bimbingan Konseling. Pada saat jam pelajaran bimbingan konseling, guru bimbingan konseling menjelaskan materi khusus terkait bahaya penyalahgunaan NAPZA. Hal itu dapat memberikan informasi kepada siswa agar nantinya siswa dapat terhindar dari bahaya barang haram tersebut. Pada kegiatan upacara, Pembina upacara juga menyampaikan beberapa amanat kepada peserta upacara terkait upaya pencegahan penyalahgunaan NAPZA.

Program sekolah tersebut tentunya juga tidak akan berjalan lancar tanpa adanya bantuan masyarakat disekitar sekolah. Dalam hal ini, sekolah juga menjalin kerjasama dengan masyarakat disekitar sekolah untuk senantiasa mengawasi siswa pada saat berada di lingkungan luar sekolah. Masyarakat juga dapat melaporkan kepada sekolah apabila melihat atau terjadi sesuatu yang mencurigakan dan meresahkan masyarakat yang dilakukan oleh siswa diluar lingkungan sekolah.

Sekolah mempunyai peranan yang sangat besar dalam upaya pencegahan penggunaan NAPZA di kalangan pelajar karena sekolah menengah berperan dalam mempersiapkan siswa untuk memasuki jenjang pendidikan yang lebih tinggi. Anak se-usia SMA merupakan remaja yang penuh dengan persoalan-persoalan dan dapat membuat mereka menjadi bingung bila tidak mendapat bantuan yang tepat, sehingga dapat membawa mereka pada perbuatan yang melanggar norma hukum, seperti penyalahgunaan NAPZA yang terjadi dalam kehidupan masyarakat, sekolah maupun di rumah.

Sekolah akan dirasa lebih baik jika menyertakan program anti NAPZA di sekolah, lembaga peribadatan, dan lembaga masyarakat di mana remaja terlibat didalamnya. Upaya 
pencegahan penyalahgunaan NAPZA menjadi tanggung jawab semua pihak. Orang tua, keluarga, masyarakat, dan sekolah hendaknya bekerjasama untuk meciptakan generasi penerus bangsa yang bebas dari NAPZA. Melalui program sekolah dalam upaya pencegahan penyalahgunaan NAPZA, siswa diharapkan dapat memiliki bekal tentang bahaya penyalahgunaan NAPZA dan dapat menghindari penggunaan NAPZA tersebut.

Dalam hal ini, upaya pencegahan penyalahgunaan NAPZA tersebut telah dilakukan oleh SMK 41 Jakarta. Sekolah memiliki program diantaranya membuat tata tertib, memberikan penyuluhan, memasukkan materi pencegahan penyalahgunaan NAPZA, hingga memiliki ektrakulikuler yang dapat menghindarkan siswa dari kejahatan NAPZA, serta bekerjasama dengan masyarakat sekitar untuk memberikan pengawasan kepada siswa saat berada di luar sekolah. Program-program tersebut dibuat agar memaksimalkan peran sekolah dalam upaya pencegahan penyalahgunaan NAPZA.

\section{Simpulan}

Berdasarkan hasil melalui observasi dan wawancara dengan guru, penulis dapat menarik kesimpulan bahwa sekolah melaksanakan program pencengahan penyalahgunaan NAPZA pada siswa di SMK 41 Jakarta. Adapun program sekolah dalam upaya pencengahan penyalahgunaan NAPZA antara lain: a) membuat tata tertib sekolah, b) melakukan razia intensif dan spontan, c) bekerjasama dengan instansi terkait guna penyuluhan dan sosialisasi d) menggunakan ekstrakurikuler sebagai sarana pencegahan, e) memasukkan materi tentang narkotika ke dalam kurikulum pengajaran, f) memaksimalkan tugas dalam upaya pencegahan penyalahgunaan NAPZA.
Melalui program-program yang dibuat sekolah diharapkan dapat membantu pemerintah dalam upaya pencegahan penyalahgunaan NAPZA, sehingga dapat memutus rantai kejahatan penyalahgunaan NAPZA dan dapat melahirkan generasi bangsa yang bebas dan anti NAPZA.

Dengan melihat dari kesimpulan dan juga permasalahan mengenai upaya pencegahan penyalahgunaan NAPZA dikalangan pelajar, maka penulis memberikan beberapa saran antara lain: a) guru hendaknya lebih memahami tentang segala bentuk, kegunaan, manfaat, kerugian dan segala sesuatu tentang NAPZA agar para guru bisa menjelaskan dan memberikan pengetahuan kepada siswanya tentang bahaya NAPZA dengan benar, karena sekolah merupakan tempat dan juga sarana yang paling efektif untuk mencegah penggunaan NAPZA. b) agar upaya pencegahan dapat berkesinambungan dan efektif maka diperlukan kerjasama yang baik dengan berbagai pihak. Pihak sekolah, orang tua siswa, serta masyarakat sekitar sekolah hendaknya bekerja sama dan memberikan perhatian karena tanpa bantuan dan kerjasama dengan orang tua dan masyarakat, sekolah tidak dapat melakukan upaya pencegahan penyalahgunaan NAPZA di kalangan pelajar dengan baik.

\section{Daftar Pustaka}

Adhani, Abrar \& Ribut Priadi. 2017. Persepsi Siswa Sekolah Menengah Atas Terhadap Sosialisasi Penyalahgunaan Narkoba di Kota Medan. Jurnal Interaksi.Volume 1. Nomor 2.

Agustin, Rinni. 2014. Persepsi Masyarakat Tentang Sosialisasi Bahaya Narkoba di Kelurahan Sidomulyo Kecamatan Samarinda Ilir Kota Samarinda. Jurnal Ilmu Komunikasi. Volume 2. Nomor 3. 
Andriani, Titi. 2011. Upaya Pencegahan Tindak Penyalahgunaan Narkoba di Kalangan Mahasiswa Politeknik Negeri Sriwijaya. Jurnal Ilmiah Orasi Bisnis. Edisi ke-VI.

Badan Narkotika Nasional Republik Indonesia. Pencegahan Penyalahgunaan Narkoba Bagi Remaja. Jakarta. 2011.

Kadarmanta, A. Narkoba Pembunuh Karakter Bangsa. Jakarta: PT Forum Media Utama. 2010.

Masum, Sumarmo. 1987. Penyalahgunaan Bahaya Narkotika dan Ketergantungan Obat. Jakarta: CV Haji Masagung.

Misna, Andi. 2015. Formulasi Kebijakan Alokasi Dana Desa di Desa Kandolo Kecamatan Teluk Pandan Kabupaten Kutai Timur. Jurnal Administrasi Negara. Volume 3. Nomor 2.

Pritha Amanda, Maudy, dkk. 2017. Penyalahgunaan Narkoba di Kalangan Remaja. Jurnal Penelitian dan PPM. Volume 4. Nomor 2.

Rahmiyati. 2015. Strategi Pencegahan Narkoba Terhadap Remaja. Jurnal Al-Hiwar. Vol. 3 No. 5.

Rasul, Djuharis. 2013. Pencegahan Penyalahgunaan Narkoba di Kurikulum Sekolah Menengah Kejuruan. Jurnal Pendidikan dan Kebudayaan. Volume 19. No. 4.
Rozi, Fahrul. Meningkatkan Peran Orangtua Siswa dalam Pencegahan Penyalahgunaan Narkoba Melalui Penyuluhan Narkoba Berdasarkan Assesmen Kebutuhan Penyuluhan. Jurnal Ilmiah Penelitian Psikologi: Kajian Empiris dan NonEmpiris. Volume 1. Nomor 1. 2015.

Sasangka, Hari. 2003. Narkotika dan Psikotropika dalam Hukum Pidana. Bandung: Mandar Maju.

Sholihah, Qomariyatus. 2015. Efektivitas Program P4GN Terhadap Pencegahan Penyalahgunaan NAPZA. Jurnal Kesehatan Masyarakat. Volume 10. Nomor 2.

Sugiyono. 2011. Metode Penelitian Kuantitiatif, Kualitatif, dan R\&D. Bandung: Alfabeta.

Umi Nurlila, Ratna, \& Jumarddin La Fua. 2017. Penyalahgunaan Zat Adiktif Pada Siswa Kelas VIII di Sekolah Menengah Pertama Negeri 05 Kota Kendari. Jurnal Al-Ta'dib. Volume 10. Nomor 1.

Wulandari, Tri. 2016. Implementasi Kebijakan Pencegahan dan Pemberantasan Penyalahgunaan dan Peredaran Gelap Narkoba (P4GN) Pada Kalangan Pelajar di BNNP DIY. Jurnal Kebijakan Pendidikan. Edisi 5. Volume V. 